Jurnal Satyagraha

Vol. 03, No. 02, Agustus 2020 - Januari 2021

ISSN : 2620-6358

http://ejournal.universitasmahendradatta.ac.id/index.php/satyagraha

\title{
PELATIHAN PENINGKATAN KAPASITAS STAKEHOLDER SEBAGAI UPAYA PENGEMBANGAN PERAN PEREMPUAN DI DESA DAWAN KELOD KECAMATAN DAWAN KABUPATEN KLUNGKUNG
}

\author{
${ }^{1}$ I Ketut Winaya., S.Sos., MAP, ${ }^{2}$ Putu Eka Purnamaningsih.,SH., MAP, ${ }^{3}$ Kadek Wiwin Dwi \\ Wismayanti., SE., MAP, dan ${ }^{4}$ Komang Adi Sastra Wijaya.,SS., MAP \\ ${ }^{1,2,3,4}$ Program Studi Administrasi Negara, FISIP, Univeritas Udayana \\ Bali, Indonesia \\ ketutwinaya14@yahoo.com, ekapurnama@unud.ac.id, wiwin.fisip@unud.ac.id \\ adi.ganain@gmail.com
}

\begin{abstract}
Abstrak--Upaya pembangunan perempuan dijelaskan bahwa menerima dan membuka ruang pada kaum perempuan untuk berperan aktif dalam pembangunan yang tercermin dalam susunan kepengurusan lembaga pemberdayaan masyarakat perempuan paling tinggi 30\% (persen) perempuan. Sesuai dengan tujuan yang hendak dicapai yaitu terbentuknya masyarakat perempuan yang mandiri serta mampu meningkatkan ekonomi mereka. Kemudian terbentuknya lembaga-lembaga dan kelompok perempuan berdasarkan inisiatif dan partisipasi kaum perempuan sendiri. Mskipun hal tersebut sudah di atur dalam Peraturan Daerah, akan tetapi relaita yang terjadi peran perempuan hingga saat ini masih sangat terbatas, selain dari partisipasi perempuan, kurangnya dukungan dari stakeholder turut menjadi faktor kemunduruan peran perempuan dalam pembangunan khususnya di Desa.

Pemangku kepentingan (stakeholder), yaitu semua pihak di dalam sebuah struktur masyarakat, yang terdiri atas individu, atau komunitas yang memiliki keterkaitan kepentingan terhadap sebuah persoalan dalam hal ini mislanya kelompok PKK yang merupakan wadah atau komunitas kegitaan perempuan di Desa. Stakeholder merupakan elemen penting dalam mewujudkan gerak langkah perubahan perempuan dalam pembangunan. Sebagai upaya mendukung pengembangan peranan perempuan dalam pembangunan berbasiskan desa, maka perlu mempertimbangkan berbagai pendekatan, baik pendekatan sektoral maupun kewilayahannya serta melibatkan partisipasi aktif dari berbagai Pemangku Kepentingan (Stakeholder) di Desa Dawan Kabupaten Klungkung. Dalam kerangka meningkatkan sinergisitas, sinkronisasi dan integrasi segenap potensi di Desa Dawan Kabupaten Klungkung, dibutuhkan suatu kegiatan penigkatan kapasitas bagi seluruh Stakeholders dalam rangka memberikan kontribusi dalam pelakasaan Pemberdayaan perempuan di tingkat daerah.

Dengan demikian dengan adanya pengabdian ini diharapkan mampu menjadi role model upaya peningkatan kulaitas stakeholder dalam rangka pembangunan perempuan di tingkat daerah di Kabupaten Klungkung.

Kata kunci; Kapasitas Stakeholder, Peran Perempuan
\end{abstract}

I Ketut Winaya., S.Sos., MAP,

Putu Eka Purnamaningsih.,SH., MAP,

Kadek Wiwin Dwi Wismayanti., SE., MAP,

Komang Adi Sastra Wijaya.,SS., MAP 


\section{Jurnal Satyagraha \\ Vol. 03, No. 02, Agustus 2020 - Januari 2021 \\ ISSN : 2620-6358}

http://ejournal.universitasmahendradatta.ac.id/index.php/satyagraha

Abstract - Women's development efforts explained that accepting and opening space for women to play an active role in development is reflected in the composition of the management of women's community empowerment institutions with a maximum of $30 \%$ (percent) of women. In accordance with the objectives to be achieved, namely the formation of an independent community of women who are able to improve their economy. Then the formation of institutions and women's groups based on the initiative and participation of women themselves. Even though this has been regulated in the Regional Regulation, but the reluctance that occurs the role of women to date is still very limited, apart from women's participation, the lack of support from stakeholders also contributes to the decline in the role of women in development, especially in the Village.

Stakeholders (stakeholders), namely all parties in a community structure, consisting of individuals, or communities who have an interest related to an issue in this case, for example the PKK group which is a forum or community of women in the village. Stakeholders are an important element in bringing about changes in women's movements in development. In an effort to support the development of women's roles in village-based development, it is necessary to consider various approaches, both sectoral and territorial approaches and involve active participation from various Stakeholders in Dawan Village, Klungkung Regency. In the framework of increasing synergy, synchronization and integration of all potentials in Dawan Village, Klungkung Regency, a capacity building activity is needed for all Stakeholders in order to contribute to the implementation of women's Empowerment at the regional level.

Therefore, this dedication is expected to be a role model for efforts to increase stakeholder quality in the context of women's development at the regional level in Klungkung Regency.

Keywords; Stakeholder Capacity, Role of Women

I Ketut Winaya., S.Sos., MAP, Putu Eka Purnamaningsih.,SH., MAP, Kadek Wiwin Dwi Wismayanti., SE., MAP, Komang Adi Sastra Wijaya.,SS., MAP 
http://ejournal.universitasmahendradatta.ac.id/index.php/satyagraha

\section{PENDAHULUAN}

Upaya

pemberdayaan

masyarakat khususnya pemberdayaan

perempuan, partisipasi dari

perempuan ini seringkali dianggap sebagai bagian yang tidak terlepas

dalam upaya pemberdayaan

perempuan.Terkait dengan konsep

partisipasi ini Soewando (1984)

bahwa peranan atau partisipasi wanita dalam pembangunan itu dapat dilihat dari dua sudut pandangan, yaitu : (a) wanita sebagai waga Negara dalam hubunganya dengan hak-hak dalam bidang sipil, politik, dan lain-lain, termasuk perlakuan pada wanita dalam partisipasi tenaga kerja, yang disebut sebagai fungsi eksteren, dan (b) wanita sebagai ibu dalam keluarga dan sebagai istri dalam hubungan rumah tanggah, yang disebut fungsi interen.

Pemberdayaan dalam kontes gender adalah pembangunan bagi perempuan dalam pengertian kemandirian dan kekuatan internal, serta menekankan kesetaraan laki-laki dan perempuan (Moose dalam Anwar, 2007).
Dalam arti ada pengakuan makna produkti terhadap aktifitas perempuan meskipun dilakukan dalam rumah tangga sepanjang dapat menambah pendapatan rumah tangga, pembangunan organisasi perempuan, peningkatan kesadaran, dan pendidikan masyarakat seagai syarat penting perubahan sosial bagi kelompok perempuan. Konsep pemberdayan perempuan ini lebih ditekankan pada keinginan atau tuntutan membagi kekuasaan, representasi dan partisipasi perempuan dalam pengambilan keputusan dalam pelaksanaan progaram pembangunan. Selain itu, wanita dalam keluarga seringkali menunjukan memiliki kemampuan untuk berperan ganda baik sebagai ibu Rumah Tangga sekaligus sebagai produsen atau penghasil atau sebagai pencari nafkah tambahan untuk menghidupi keluarga (Sajogyo, 1983).

\section{Lingkungan keluarga} merupakan tempat pertama yang memiliki pengaruh cukup besar bagi

I Ketut Winaya., S.Sos., MAP, 
perempuan untuk berpartisipasi dalam kegiatan di ranah publik. Dorongan dari anggota keluarga seperti suami dan anak-anak menjadi suatu faktor penting dalam memotivasi perepuan untuk melakukan kegiatan sosial dengan terlibat dalam kegiatan sebagai anggota kelembagaan setidaknya di tingkat desa. Meskipun demikian, perempuan tetap dituntut untuk pandai-pandai membagi waktu dengan tidak mengeksampingkan kepentingan keluarga karena peran aktifnya dalam berorganisasi. Selain dukungan lingkungan keluarga, dukungan secara eksternal dari lingkungan luar pada umumnya juga menjadi faktor yang mempegaruhi kapasitas peran perempuan dalam kelembagaan desa.

Kondisi atau realita yang ada pada saat ini, khususnya di desa Dawan Kelod masih terdapat adanya kendala atau hambatan bagi perempuan untuk berpartisipasi dalam proses pembangunan, baik dari sisi kebijakan, peraturan dan perundangan; kultur, budaya, norma, adat, agama; lingkungan keluarga maupun lingkungan pada umumnya. Kesadaran terhadap peran sebagai wakil kaum perempuan di tingkat desa dinilai masih sangat kurang. Hal ini tercermin dari tingkat kehadiran dan keterlibatan dalam penyusunan rencana, pelaksanaan kegiatan maupun dalam monitoring dalam aktivitas kegiatan PKK dan organisasi Desa lain yang sangat minim dalam melibatkan perepmpuan. Akses dan kontrol perempuan dalam perencanaan, pelaksanaan, monitoring dan evaluasi, manfaat hasil pembangunan desa masih sangat kurang. Sehigga diperlukan pemahaman pemahaman baru bagi stakholder dan para pemangku kepentingan di Lingkungan Desa Dawan Kelod untuk mendrong keterlibatan perempuan dalam membangun desa.

Namun demikian, kapasitas perempuan untuk memperjuangkan kebutuhan mereka dalam pembangunan masih harus

I Ketut Winaya., S.Sos., MAP, 
http://ejournal.universitasmahendradatta.ac.id/index.php/satyagraha

ditingkatkan. Selain itu, saat ini kondisi masyarakat di desa yang masih paternalistik, menjadi tantangan yang harus dihadapi. Pemaaman mengenai perempuan yang mampu melakukan kegiatan multitasking perlu ditekankan kepada stakeholder dan masyarakat. Perempuan, dinilai mampu mengidentifikasi kebutuhankebutuhan masyarakat yang tidak terpikirkan oleh laki-laki seperti misalnya kebutuhan di bidang kesehatan, pendidikan, simpan pinjam dan air bersih. Selain itu, perempuan dinilai dapat bersikap lebih obyektif dalam menentukan prioritas kebutuhan.

Menanggapi besarnya potensi sumbangsih kaum perempuan dalam pembangunan ini, upaya pemerintah seharusnya lebih intensif lagi. Tidak dapat dipungkiri bahwa sistem tatanan adat istiadat Indonesia yang lebih banyak menganut patriarki bisa menjadi salah satu faktor penghambat optimalisasi peran perempuan. Selain itu, kapasitas perempuan dalam menyuarakan pendapatnya masih harus ditingkatkan. Memotivasi ibuibu untuk terlibat dalam pengambilan keputusan merupakan sebuah masalah yang tidaklah mudah. Sebagai contoh latar belakang kaum perempuan Bali yang secara budaya lebih mengedepankan adat istiadat menjadi masalah keterbatasan waktu untuk ikut berpartisipasi dalam proses pembangunan desa, membuat mereka tidak percaya diri dalam menyuarakan pendapatnya. Namun dengan adanya musyawarah khusus perempuan yang kerap diadakan, lambat laun mereka mulai terbiasa menyampaikan aspirasinya. Cara yang paling baik dalam memotivasi perempuan adalah dengan melakukan pendekatan kepada kelompokkelompok karena dalam kelompok tersebut mempunyai kekuatan dalam menggerakkan perempuan. Kemudian dari kelompok dibangun komunikasi dan sosialiasi yang lebih intens karena informasi biasanya didapat dari hubungan komunikasi dan sosialisasi yang baik.

I Ketut Winaya., S.Sos., MAP, 53

Putu Eka Purnamaningsih.,SH., MAP,

Kadek Wiwin Dwi Wismayanti., SE., MAP,

Komang Adi Sastra Wijaya.,SS., MAP 
http://ejournal.universitasmahendradatta.ac.id/index.php/satyagraha

\begin{abstract}
Pada penelitian ini akan difokuskan pada bagaimanakah kapasitas stakeholder dalam meningkatkan peran perempuan secara partisipatif dalam kegiatan sosial kemsayrakatan di tingkat desa di Desa Dawan Kelod Kabupaten Klungkung , maka rumusan masalah yang hendak di jawab pada penelitian ini, yaitu bagaimana peran dan kapasitas stakeholder dalam meningkatkan peran perempuan di desa Dawan Kabupaten Klungkung?
\end{abstract}

\section{METODE DAN PROSEDUR}

$$
\text { Kegiatan pengabdian }
$$

masyarakat ini dilaksanakan dengan metode edukasi dan workshop terkait pentingnya peran perempuan dalam pembangunan desa. Metode edukasi dilakukan melalui ceramah dengan maksud memberikan kelompok perempuan Desa Dawan Kelod pengetahuan tentang pentingnya partisipasi dan kuota perepmpuan di dalam kegiatan pemerintahan serta kegiatan organisasi sosial yang dimulai di tingkat desa. Berbekal pengetahuan tersebut perempuan diharapkan akan semakin sadar dan peduli dengan kekuatan peran mereka dalam membuat perubahan dalam pembangunan. Berikutnya adalah pelatihan kepada stakeholder dalam mengelola dan memberdayakan perempuan di Desa Dawan Kelod, dengan memberikan edukasi penganggaran dan program untuk menggerakkan perempuan di Desa Dawan Kelod Kecamatan Dawan Kabupaten Klungkung. selanjutnya dibentuk kelompok kelompok kecil dari ibu ibu PKK Desa setempat untuk selanjutnya melakukan diskusi ringan mengenai perencanaan program pemerintahan khusus perempuan dan sesi tanya jawab serta ditutup dengan kuis.

\section{HASIL DAN PEMBAHASAN}

Kegiatan pengabdian yang mengambil tema "PELATIHAN PENINGKATAN KAPASITAS STAKEHOLDER SEBAGAI UPAYA PENGEMBANGAN PERAN PEREMPUAN DI DESA DAWAN KELOD KECAMATAN DAWAN KABUPATEN 
http://ejournal.universitasmahendradatta.ac.id/index.php/satyagraha

KLUNGKUNG” yang dilaksanakan di Kantor Desa Dawan Kelod Kcamatan Dawan Kabupaten Klungkung dilakukan dalam beberapa tahap yaitu:

Adapun metode pelaksanaan atau tahapan kegiatan pengabdian ini adalah sebagai berikut :

a) Tahapan Pemetaan

Pemetaan kelompok perempuan di Desa Dawan Kelod Kecamatan Dawan Kabupaten Klungkung. Diketahui kelompok Perempuan di Desa Dawan Kelod dalam konteks tertentu (kegiatan sosial dan pemerintahan desa) kurang berpartisipasi aktif dalam berorganisasi. Hal inilah yang dirasakan perlu untuk memulai upaya memetakan situasi perempuan melalui kegiatan pengabdian di Desa Dawan Kelod ini.

dengan organisasi yang merangkul kelompok perempuan di Desa Dawan Kelod seperti Kelompok PKK Desa Dawan Kelod.

3.

I Ketut Winaya., S.Sos., MAP, 55

Putu Eka Purnamaningsih.,SH., MAP,

Kadek Wiwin Dwi Wismayanti., SE., MAP,

Komang Adi Sastra Wijaya.,SS., MAP
4. Korespondensi dan koordinasi dengan pemberi materi workshop Ibu Chantika Devi dari Lembaga Pemberdayaan Peran Perempuan.

b) Tahapan Pelaksanaan

Pelaksanaan workshop dan sosialisasi peran perempuan di Desa Dawan Kabupaten Klungkung di pandu oleh Ibu Putu Eka Purnmaningsih., SH., MAP. Pembagian sembako dilakukan pada hari Kamis 23 Juli 2020. Acara pembagian sembako dimanfaatkan sekalian dengan memberikan sosialisasi covid19. Pembagian sembako dilaksanakan di halaman Kantor Desa Dawan Kelod Kecamatan Dawan Kabupaten Klungkung.

Pelaksanaan kegiatan diantaranya yaitu

1. Tahapan persiapan dilaksanakan dengan mengadakan audiensi kepada pihak Desa Dawan Kelod bersama perwakilan stakehlder dan beberapa perwakilan anggota kelompok 
Jurnal Satyagraha

Vol. 03, No. 02, Agustus 2020 - Januari 2021

ISSN : 2620-6358

http://ejournal.universitasmahendradatta.ac.id/index.php/satyagraha

perempuan yang diwakili oleh PKK

Desa Dawan Kelod serta melibatkan

perwakilan anggota Teruni dari STT

di Lingkungan Desa Dawan Kelod.

Audiensi bertujan untuk

menyampaikan maksud tujuan dan

mempresentasikan konsep kegiatan

yang akan dilaksanakan. Audiensi

berlangsung di aula pertemuan

Kantor Desa Dawan Kelod. Dalam

audiensi menghasilkan kesepekatan

peserta dan timetable kegiatan serta

mekanisme pelaksanaan kegiatan

workshop peran perempuan dan

pembagian bantuan sosial sembako

terkait pandemi covid19.

Penyampaian informasi kegiatan

dilakukan oleh ketua Pengabdian

Program Udayana Mengabdi

2. Pelaksanaan workshop dan sosialisasi peran perempuan di Desa Dawan Kabupaten Klungkung di pandu oleh Ibu Putu Eka Purnmaningsih., SH., MAP. Acara dimulai di pagi hari pukul 10.00 WITA dengan diawali dengan pembukaan beserta sambutan serta pemaparan maksud dan tujuan kegiatan. Kegiatan dihadiri oleh kelompok PKK Desa Dawan Kelod dan beberapa perwakilan Teruni dari STT di lingkungan Desa Dawan Kelod. Kegiatan dilanjutkan dengan pemaparan materi yang berkaitan dengan Perempuan Dalam Pembangunan yang disampaikan oleh Ibu Chantika Devi perwkilan dari Lembaga Pemberdayaan Peran Perempuan Kabupaten Klungkung.

3. Pemaparan materi dilanjutkan dengan sesi tanya jawab dan diwarnai dengan antusiasme Ibu Ibu di desa Dawan Kelod. Selanjutnya kegiatan disambung dengan kuis megenai materi dengan beberapa hadiah bingkisan kecil bagi peserta yang dapat menjawab pertanyaan dengan benar. Workshop dilanjutkan dengan membentuk ibu ibu dalam bebrapa kelompok kecil untuk melaksanakan game ringan yang terkait dengan pemecahan masalah dan pengambilan keputusan. 
http://ejournal.universitasmahendradatta.ac.id/index.php/satyagraha

Hasil Temuan Peneliti

\section{KETERLIBATAN PEREMPUAN DALAM KELEMBAGAAN DESA}

Keterlibatan perempuan

dalam kelembagaan Pembangunan

Desa Lingkungan keluarga memiliki pengaruh yang cukup besar bagi perempuan untuk berpartisipasi dalam kegiatan di ranah publik. Dorongan dari anggota keluarga seperti suami dan anak-anak untuk melakukan kegiatan sosial dengan terlibat sebagai anggota PKK. Meskipun demikian menurut penuturan para responden, harus pandai-pandai membagi waktu, jangan sampai kepentingan keluarga terabaikan karenanya. Selain dukungan lingkungan keluarga, dukungan dari lingkungan luar pada umumnya juga sebagai faktor pendukung peran perempuan dalam kelembagaan desa (PKK). Dari beberapa deskripsi sebelumnya dan informasi dari responden, pada saat ini khususnya di desa Dawan Kelod dapat dikatakan hampir tidak ada kendala atau hambatan bagi perempuan untuk berpartisipasi dalam proses pembangunan, baik dari sisi kebijakan, peraturan dan perundangan; kultur, budaya, norma, adat, agama; lingkungan keluarga maupun lingkungan pada umumnya Dari profil aktivitas partisipasi perempuan PKK di Desa Dawan Kelod sangat tinggi, lebih besar dari target yang ditetapkan. Kesadaran terhadap peran sebagai wakil warga, cukup tinggi hal ini tercermin dari tingkat kehadiran dan keterlibatan dalam penyusunan rencana, pelaksanaan kegiatan maupun dalam monitoring. Akses dan kontrol perempuan dalam perencanaan, pelaksanaan, monitoring dan evaluasi, manfaat hasil pembangunan cukup besar.

Selain itu semua informan menyatakan tidak ada kendala bagi perempuan untuk berpartisipasi dalam kelembagaan desa (PKK). Partisipasi kaum perempuan dalam derap pembangunan di desa, khususnya dalam PNPM, menunjukkan peningkatan. Data

I Ketut Winaya., S.Sos., MAP, 
yang diperoleh Bidang Pembinaan

Tim Koordinasi PNPM Pusat dan

Daerah PMD (Pemberdayaan Masyarakat Desa) Departemen Dalam Negeri (Depdagri) mencatat bahwa hampir $30 \%$ usulan program berasal dari inisiatif kaum perempuan. Sementara usulan program dari suara campuran hanya berkisar 14\%. Besarnya partisipasi aktif perempuan ini dinilai menyumbang cukup tinggi pada keberhasilan PNPM. Namun demikian, kapasitas perempuan untuk memperjuangkan kebutuhan mereka dalam pembangunan masih harus ditingkatkan. Selain itu, kondisi masyarakat kita yang masih paternalistik, menjadi tantangan yang masih harus dihadapi. Perempuan, dinilai mampu mengidentifikasi kebutuhan-kebutuhan masyarakat yang tidak terpikirkan oleh laki-laki seperti misalnya kebutuhan di bidang kesehatan, pendidikan, simpan pinjam, air bersih atau jembatan penghubung ke desa lain. Selain itu, perempuan dinilai dapat bersikap lebih obyektif dalam menentukan prioritas kebutuhan.

Menanggapi besarnya potensi sumbangsih kaum perempuan dalam pembangunan ini, upaya pemerintah tampaknya harus lebih intensif lagi. Tak bisa kita pungkiri bahwa sistem tatanan adat istiadat Indonesia yang lebih banyak menganut patriarki bisa menjadi salah satu faktor penghambat optimalisasi peran perempuan. Selain itu, kapasitas perempuan dalam menyuarakan pendapatnya masih harus ditingkatkan. Memotivasi ibu-ibu untuk terlibat dalam pengambilan keputusan tidaklah mudah. Latar belakang pendidikan kaum perempuan yang rata-rata tidak lulus $\mathrm{SD}$, membuat mereka tidak percaya diri untuk menyuarakan pendapatnya. Namun dengan adanya musyawarah khusus perempuan yang kerap diadakan, lambat laun mereka mulai terbiasa menyampaikan aspirasinya. Cara yang paling baik dalam memotivasi perempuan adalah dengan melakukan pendekatan

I Ketut Winaya., S.Sos., MAP, 
kepada kelompok-kelompok karena kelompok itu mempunyai kekuatan. Kemudian dari kelompok dibangun jejaring karena informasi biasanya didapat dari hubungan jejaring.

KONDISI PERAN PEREMPUAN DI DESA DAWAN KELOD

\section{Peran Perempuan melalui}

PKK Gerakan PKK bertujuan untuk menunjang pembangunan dan keahlian dalam berorganisasi khususnya di Desa Dawan Kelod, dari berbagai macam kegiatan yang dilakukan bertujuan untuk meningkatkan kesejahteraan keluarga yang ada dipedesaan khususnya Desa Dawan Kelod Kabupaten Klungkung. Pemerintah Kabupaten Klungkung pada umumnya sangat mendukung adanya Gerakan PKK dan kegiatankegiatan yang diprogramkan juga dilaksanakan oleh pihak PKK di Desa Dawan Kelod. Pemerintah Desa Dawan Kelod juga sudah berupaya membantu Tim Penggerak PKK tersebut baik itu dalam hal dana
/ fasilitas (materil) maupun bantuan berupa pemikiran / motivasi (moril). Dari bantuan tersebut para penggerak PKK dapat menjalankan program yang sudah direncanakan. Kemudian partisipasi para Istri pejabat pemerintah desa untuk menjadi Tim Penggerak PKK juga sangat membantu proses berjalannya lembaga PKK tersebut dan atusiasnya para warga / ibu-ibu rumah tangga untuk terlibat dalam lembaga PKK tersebut sangat membantu proses terlaksananya program PKK. Kerja sama dari pihak tersebut hingga saat ini masih terjalin erat sehingga PKK di Desa Dawan Kelod masih dapat eksis hingga saat ini.

Untuk program / kegiatan PKK di Desa Dawan Kelod sendiri sejauh ini sudah berjalan dan Pemberdayaan Perempuan juga telah dijalankan sesuai dengan 10 Program Pokok PKK, akan tetapi di dalam pengaplikasian 10 Program Pokok PKK tersebut belum berjalan dengan maksimal, karena dalam upaya

I Ketut Winaya., S.Sos., MAP, 59

Putu Eka Purnamaningsih.,SH., MAP,

Kadek Wiwin Dwi Wismayanti., SE., MAP,

Komang Adi Sastra Wijaya.,SS., MAP 
Jurnal Satyagraha

Vol. 03, No. 02, Agustus 2020 - Januari 2021

ISSN : 2620-6358

http://ejournal.universitasmahendradatta.ac.id/index.php/satyagraha

Pemberdayaan Perempuan,

antusiasnya ibu-ibu terhadap

Program PKK masih rendah, serta

rendahnya pemahaman warga / ibu-

ibu rumah tangga terhadap

pentingnya program PKK yang

sebenarnya dapat lebih

mensejahterakan hidupnya dan

rendahnya pemahaman warga

terhadap pentingnya hidup

bermasyarakat sosial atau

berorganisasi juga turut menjadi

penghambat masyarakat untuk aktif

ke dalam lembaga PKK.

Berdasarkan hasil observasi peneliti

di lapangan di ketahui bahwa saat ini

program atau kegiatan PKK yang

sudah berjalan adalah kegiatan

Pertemuan rutin yang di laksanakan

setiap Dua Minggu sekali yaitu

setiap hari Sabtu yang dilaksankan

secara bergiliran di rumah warga.

Kemudian Kegiatan selanjutnya

adalah Arisan PKK yang di

laksanakan Sebulan sekali yang

dilaksankan ketika Pelaksanaan

Kegiatan Pertemuan Rutin.
Program atau Kegiatan selanjutnya adalah Posyandu yang dilakukan sebulan sekali di Puskesmas Pembantu (Pusban). Serta ada beberapa Kegiatan dadakan yang sering dilaksanakan kegiatan masakmemasak ketika ada pertemuan tertentu dan lain-lain. Pemberdayaan dan Kesejahteraan Keluarga (PKK) merupakan salah satu organisasi yang dibawah strukutur Pemerintah Desa Dawan Kelod, PKK Desa Dawan Kelod sebagai tempat para wanita sebagai pelopor penggerak pembangunan yang diwadahi melalui PKK. PKK yang merupakan gerakan pembangunan masyarakat, yang bermula dari Seminar Home Economic di Bogor pada Tahun 1957, serta disusunnya mata pelajaran pendidikan kesejahteraan keluarga Tahun 1961 (10 Segi pokok Kehidupan Keluarga) yang sekarang dikembangkan menjadi, Pemberdayaan dan Kesejahteraan Keluarga dan 10 Program Pokok PKK. 10 Program Pokok PKK yaitu terdiri dari : 1. Penghayatan dan Pengamalan Pancasila 2. Gotong

I Ketut Winaya., S.Sos., MAP, 60

Putu Eka Purnamaningsih.,SH., MAP,

Kadek Wiwin Dwi Wismayanti., SE., MAP,

Komang Adi Sastra Wijaya.,SS., MAP 
royong 3. Pangan 4. Sandang 5. Perumahan dan tata laksana rumah tangga 6. Pendidikan dan keterampilan 7. Kesehatan 8 . Mengembangkan hidup berkoprasi 9. Kelestarian lingkungan hidup 10. Perencanaan sehat

\section{FAKTOR PENDUKUNG KETERLIBATAN PEREMPUAN MELALUI PKK DI DESA DAWAN KELOD}

a) Upaya Ketua PKK dalam mengajak ikut serta didalam kegiatan selama ini untuk menambah wawasan ibu-ibu rumah tangga di Desa Dawan Kelod yang tidak memiliki pekerjaan sehingga menjadi memiliki pekerjaan sebagai penambah penghasilan rumah tangga mereka itu sendiri.

b) Adanya hubungan yang kondusif antara ibu-ibu Desa Dawan Kelod dengan Ketua PKK Desa Dawan Kelod dan anggotanya didalam menjaga jalinan komunikasi dan silaturahmi yang baik sebagai sesama warga Desa Dawan Kelod. c) Sikap keterbukaan Ketua PKK menerima sumbang kritik dan saran Ibu-ibu atau warga Desa Dawan Kelod dan anggota nya mengenai kiat dan usaha yang dilakukan dalam pemberian pengetahuan dan wawasan yang pernah diberikan selama ini.Upaya Ketua PKK di dalam memberdayakan Ibu-ibu Desa Dawan Kelod dan anggotanya didalam Pembinaan (Pendidikan dan Pelatihan) serta Memotivasi dan memfasilitasi mereka agar bisa menambah pengalaman serta wawasan dan pengetahuan yang telah ada dan diberikan menjadi lebih baik lagi kedepannya.

\section{SIMPULAN}

Berdasarkan penjelasan di atas, dapat disimpulkan bahwa Partisipasi perempuan dalam pembangunan desa Dawan Kelod Kecamatan Dawan cukup baik dan signifikan. Partisipasi yang mendukung pembangunan itu dapat dilihat dalam kualitas capaian indikator, yakni: Dalam hal cakupan

I Ketut Winaya., S.Sos., MAP,

Putu Eka Purnamaningsih.,SH., MAP,

Kadek Wiwin Dwi Wismayanti., SE., MAP,

Komang Adi Sastra Wijaya.,SS., MAP 
yang terkena dampak dari hasil-hasil

keputusan atau proses pembangunan, semua orang terlibat dalam proses proyek pembangunan desa di kecamatan Dawan tanpa membedakan jenis kelamin. Dalam hal kesetaraan dan kemitraan (Equal Partnership), ada kesetaraan dan kemitraan dalam setiap proses guna membangun dialog tanpa memperhitungkan jenis kelamin dan struktur masing-masing pihak dalam upaya pembangunan desa Dawan Kelod Kabupaten Klungkung.

Dalam hal transparansi, semua pihak telah dapat menumbuhkembangkan komunikasi dan iklim berkomunikasi terbuka dan kondusif sehingga menimbulkan dialog dalam proses pembangunan desa. Dalam hal kesetaraan kewenangan (Sharing Power/Equal Powership) dalam pembangunan desa, berbagai pihak yang terlibat dapat menyeimbangkan distribusi kewenangan dan kekuasaan untuk menghindari terjadinya dominasi gender tertentu. Ukuran partisipasi perempuan dalam pembangunan dapat dilihat secara nyata dalam peran kaum perempuan dalam berbagai bidang kehidupan, diantaranya adalah dalam bidang sosial, dalam bidang adat dan lingkungan, politik dan pemerintahan, pendidikan, kesehatan dan kesejahteraan, dan dalam bidang olah raga, kesenian dan pariwisata melalui Program Pokok PKK di wilayah setempat.

Adapun fator-faktor yang
menjadi peran perempuan dalam
pembangunan desa di Desa Dawan Kelod seperti dari faktor Internal Peran ganda sebagai ibu rumah tangga dan wanita karier. Adapun faktor-faktor yang menjadi hambatan peran ganda perempuan dalam pembangunan desa faktor internal meliputi, peran ganda sebagai ibu rumah tangga dan wanita karier, pandangan masyarakat yang meragukan kemampuan perempuan dalam memimpin, pendidikan, pengalaman.

I Ketut Winaya., S.Sos., MAP, 


\section{DAFTAR PUSTAKA}

[1]Arsyad, Azhar. (2003). [5] Sani, A.F.I (2018, Januari 25) Manajemen Pengetahuan Praktis Survei SMRC: 87,6 Persen Bagi Pimpinan Masyarakat Menilai Partisipasi \&Eksekutif,Manajemen Strategik. Perempuan Kurang. Tempo.co

Pustaka Pelajar. Yogyakarta.

[6] Batubara, H. (2016, Januari 24)

[2] BPS Provinsi Bali. 2016. Bali dalam Angka Tahun 2016. Biro

Pusat Statistik : Denpasar; Unit Penelitian FISIP Universitas Udayana, 2015. Laporan Hasil Penelitian Tahun 2010- 2015. FISIP

Unud : Denpasar

[3]Maridjan, Kacung, 2010, Sistem

Politik Indonesia: Konsolidasi

Demokrasi Pasca- Orde Baru, Penerbit Prenada Media Group : Jakarta;

Sanit, Arbi, 2010, Sistem Politik Indonesia, Penerbit Rajawali Press : Jakarta

[4]Yudah, A. A. P. (2017). Representasi Transgender dan Transeksual dalam Pemberitaan di Media Massa: Sebuah Tinjauan Analisis Wacana Kritis. Jurnal Kriminologi Indonesia, 9(2).

Menristek: Saya Larang LGBT di Semua Kampus, Itu Tak Sesuai Nilai Kesusilaan. detikNews

[7] Kali, A. (2013). Diskursus Seksualitas Michel Foucault. Yogyakarta: Solusi Offset

[8]Ida, R. (2010). Respon Komunitas Waria Surabaya Terhadap Konstruksi Subyek Transgender di Media Indonesia. Surabaya: Departemen Komunikasi FISIP, Universitas Airlangga, tahun, 23, 221-2

I Ketut Winaya., S.Sos., MAP, 63 Putu Eka Purnamaningsih.,SH., MAP, Kadek Wiwin Dwi Wismayanti., SE., MAP, Komang Adi Sastra Wijaya.,SS., MAP 